\title{
ANALISIS DERAJAT KEJENUHAN SIMPANG TIGA LENGAN JALAN RAYA PASAR PATIKRAJA
}

\section{ANALYSIS LEVEL OF SATURATION 3-WAY JUNCTION OF PATIKRAJA MARKET HIGHWAY}

\author{
Iskahar ${ }^{1}$, Sulfah Anjarwati ${ }^{1}$, Khalifah Noor Aziz ${ }^{2}$ \\ ${ }^{12}$ Program Studi S1 Teknik Sipil, Fakultas Teknik dan Sains \\ Universitas Muhammadiyah Purwokerto
}

\section{Informasi Artikel \\ Dikirim, \\ Direvisi, \\ Diterima,}

\section{Korespondensi Penulis:}

Iskahar

Program Studi Teknik Sipil Universitas Muhammadiyah Purwokerto

JL. K.H. Ahmad Dahlan

Purwokerto, 53182

Email:

iskaharoke@gmail.com

\begin{abstract}
ABSTRAK
Simpang jalan merupakan tempat terjadinya konflik lalulintas. Volume lalulintas yang dapat ditampung oleh jaringan jalan ditentukan dengan kapasitas simpang pada jaringan jalan tersebut. Simpang yang dianalisa pada penelitian ini adalah simpang tak bersinyal tiga lengan JL. Raya PasarPtikraja. Padapersimpangan tersebut sering terjadi kemacetan dan kecelakaanlalulintas.

Data yang peneliti peroleh didapat dari data skripsi dari tahun sebelumnya. Data tersebut peneliti analisis dengan menggunakan MKJI 1997, didapatkanhasil volume kendaraan pada tahun 2019 sebesar $5400 \mathrm{Kend} / \mathrm{jam}$ dan DS $=1,49 \geq 0,75$ (Jenuh). Sehingga membuat beberapa penanganan berupa skenario I, II, III. Dari beberapa skenario yang dilakukan, terpilih skenario III yaitu dengan perubahan teknis simpang tak bersinyal menjadi simpang bersinyal menggunakan 3 fase diperoleh nilai DS $=0,52 \leq 0,75$ (tidak jenuh), yaitu kondisi dimana suatu simpang tidak mengalami kemacetan/keramian.
\end{abstract}

Kata Kunci : Derajat kejenuhan, Lalu lintas, Simpang Tak Bersinyal, Volume lalu lintas

\section{ABSTRACT}

Intersection is a place of traffic conflicts. The volume of traffic can be accommodated by the road network is determined by the capacity of the intersection in the road network. Intersections analyzed in this study are three-arm unsignalized intersections at JL. Raya Pasar Patikraja. At these intersections, traffic jams and traffic accidents often occur.

The data was obtained by the researcher were obtained fromprevious year's research. The researchers analyzed data using the MKJI 1997, the result obtained by the volume of vehicles in 2019 amounted to $5400 \mathrm{Kend} /$ hour and DS $=1.49 \geq 0.75$ (Saturated). So that the handling is making by scenario I, namely by widening the main road B and main road $\mathrm{D}$ with a widening of 4 meters and minor road $\mathrm{C}$ with a widening of $75 \mathrm{~cm}$, obtained DS $=1.34 \geq 0.75$ (Saturated). The second scenario is by adding roundabouts with a diameter of 4 meters, obtained DS $=1.2 \geq 0.75$ (saturated). And the last, the third scenario is changing the type of intersection into a signal using 3 phases, obtained DS = $0.51 \leq 0.75$ (Not Saturated).

Keyword : Degree of saturation, Traffic, Traffic volume, Unsignalized Intersection 


\section{PENDAHULUAN}

Semakin meningkatnya pertumbuhan penduduk dikabupaten Banyumas dan berkembangnya sarana transportasi mengakibatkan semakin meningkatnya jumlah kendaraan yang tersebar dijalan. Untuk itu diperlukan sarana dan prasarana transportasi untuk menunjang kebutuhan masyarakat. Namun jika sarana dan prasarana kurang memadai sering kali menimbulkan permasalahan khususnya di persimpangan. Salah satu persimpangan yang mengalami permasalahan tersebut adalah persimpangan Jalan Raya Pasar Patikraja.

Simpang jalan merupakan tempat terjadinya konflik lalu lintas. Parameter yang digunakan untuk menilai kinerja suatu simpang tak bersinyal yaitu: kapasitas, derjat kejenuhan, tundaan dan peluang antrian. Dengan menurunya kinerja simpang akan mengakibatkan kerugian pada pengguna jalan, karena terjadinya penurunan kecepatan, peningkatan tundaan, dan antrian kendaraan.

MKJI (1997) menyatakan bahwa angka kecelakaan pada simpang tak bersinyal diperkirakan sebesar 0,60 kecalakaan/juta kendaraan, dikarenakan kurangnya perhatian pengemudi terhadap rambu YIELD dan rambu STOP (Sukarno, dkk, 2003), sehingga mengakibatkan perilaku pengemudi melintasi simpang mempunyai perilaku tidak menunggu celah dan memaksa untuk menempatkan kendaraan pada ruas jalan yang akan dimasukinya, hal ini mengakibatkan konflik arus lalu lintas yang mengakibatkan kemacetan lalu lintas bahkan berpotensi untuk terjadinya kecelakaan.

\section{METODE PENELITIAN}

\subsection{Tahap Penelitian}

Dalam melaksanakan penelitian bebrapa tahapan yang dilakukan adalah sebagai berikut:

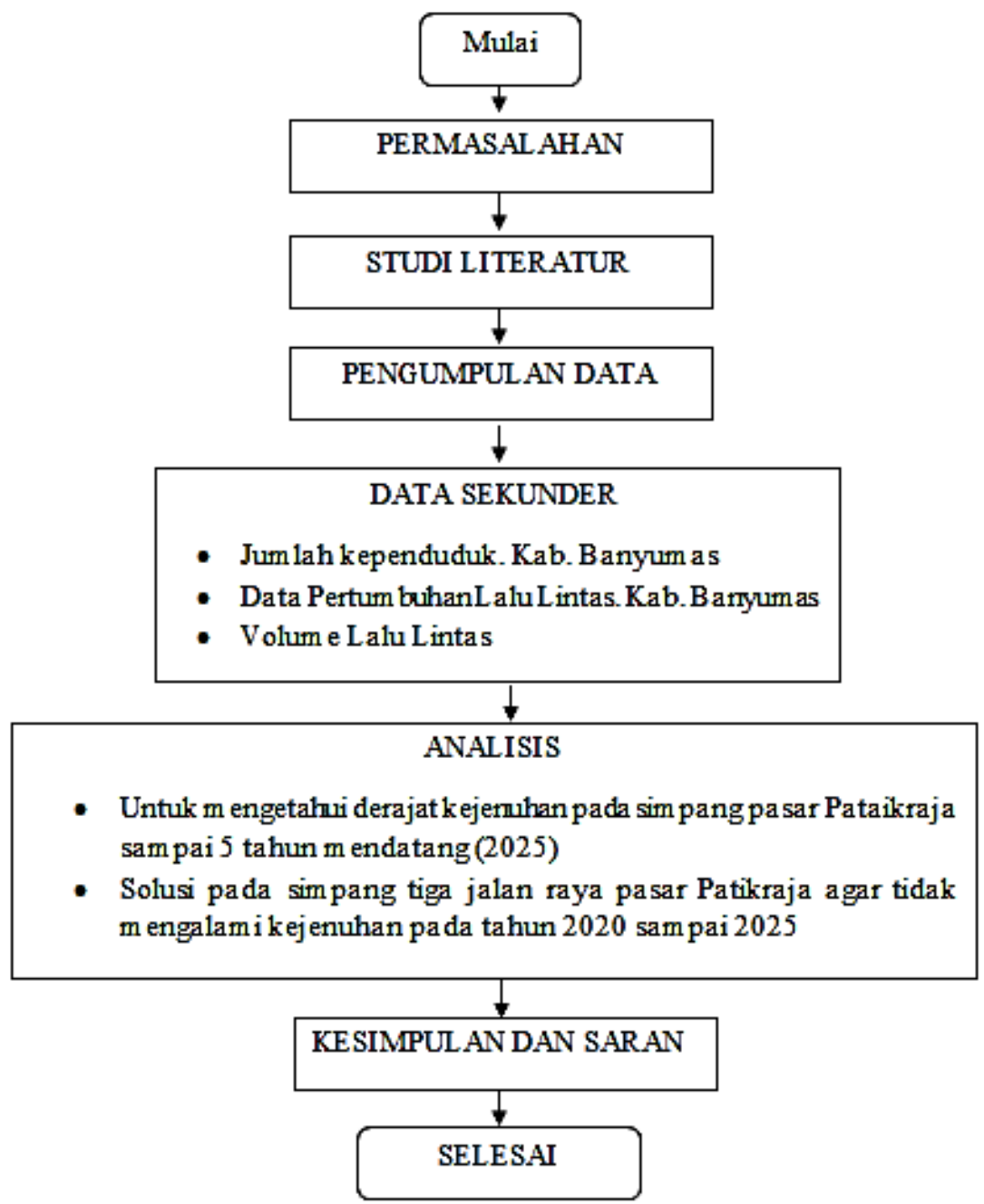

Gambar 1. Tahapan penelitian 


\subsection{Lokasi Penelitian}

Lokasi penelitian ini berada di simpang tak bersinyal tiga lengan di JL.Raya Pasar Patikraja
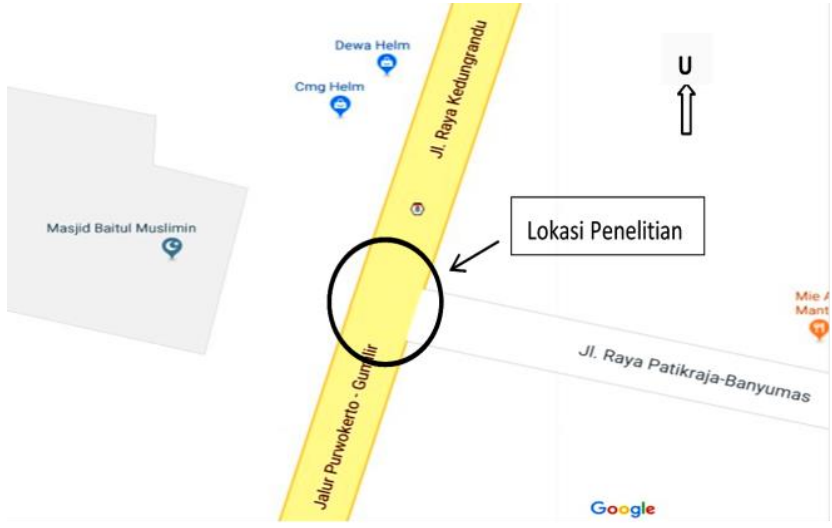

Gambar 2. Lokasi Penelitian

\subsection{Pengumpulan Data}

Data Sekunder

Didapat dari instansi terkait yaitu Bina Marga, buku refrensi yang mendukung. Data sekunder meliputi data kependudukan 2019 dan data data pertumbuhan kendaraan.

\subsection{Analisis Data}

Analisis Data adalah cara untuk mengolah data menjadi informasi sehingga karakteristik data tersebut bias dipahami dan bermanfaat untuk solusi permasalahan. Data ini merupakan Data yang diperoleh dilapangan kemudian di analisis berdasarkan Manual Kapasitas Jalan Indonesia (MKJI, 1997) untuk mengetahui kondisi kinerja dari samping yang diteliti. Dari hasil tersebut di dapat nilai kapasitas dan derajat kejenuhan berdasarkan metode yang ada di dalam buku Manual Kapasitas Jalan Indonesia (Drijen Bina Marga, 1997). Apabila simpang yang diteliti tidak memenuhi syarat sesuai dengan buku Manual Kapasitas Jalan Indonesia (Drijen Bina Marga, 1997), Maka perlu dilakukan perbaikan atau pemecahan masalah tingkat pelayanan dan kinerja simpang.

- Mencari tahun pertumbuhan lalulintas ( $i$ ) dengan analisis regresi linier sederhana.

- Derajat kejenuhan (DS) setelah didapat analisis tahun 2019-2024 pada penelitian terdahulu kemudian dapat dihitung dengan rumus derajat kejenuhan.

- Kapasitas simpang (C) setelah di dapat analisis tahun 2019-2024 pada penelitian terdahulu kemudian dapat dihitung dengan menggunkan rumus kapasitas simpang.

\section{HASIL DAN PEMBAHASAN}

\subsection{Analisis Pertumbuhan Lalu Lintas}

\section{Data Jumlah Kendaraan Terdaftar di Banyumas}

Pertumbuhan lalu lintas dianggap sebanding dengan pertumbuhan kendaraan, dengan demikiandapat diartikan pertumbuhan lalu lintas dapat diestimasi dengan pertumbuhan jumlah kendaraan. Prediksi pertumbuhan regional sangat dibutuhkan kuhususnya mengetahui transportasi yang akan datang. Data Jumlah Kendaraan Terdaftar di Banyumas tercatat dalam tabel 4.1 dibawah ini:

Tabel 1. Data Jumlah Kendaraan terdaftar di Banyumas

\begin{tabular}{cccc}
\hline Tahun & Mobil $(\mathbf{L V})$ & Truk $(\mathbf{H V})$ & Sepeda Motor $(\mathbf{M C})$ \\
\hline 2015 & 31644 & 13389 & 285911 \\
2016 & 35057 & 14134 & 311741 \\
2017 & 38440 & 14979 & 337304 \\
2018 & 41969 & 15741 & 363359 \\
2019 & 45190 & 16328 & 388121 \\
\hline Sumber : UP3AD SAMSAT Kabupaten Banyumas & &
\end{tabular}

\subsection{Analisis Pertumbuhan Kendaraan}

- Pertumbuhan Sepeda Motor (MC) 
Pertumbahan sepeda motor dapat dilihat dalam tabel 2. dibawah ini:

Tabel 2. Pertumbuhan Sepeda Motor (MC)

\begin{tabular}{cc}
\hline Tahun & Sepeda Motor $(\mathrm{MC})$ \\
\hline 2015 & 285911 \\
2016 & 311741 \\
2017 & 337304 \\
2018 & 363359 \\
2019 & 388121 \\
\hline Sumber: UP3AD SAMSAT Kabupaten Banyumas
\end{tabular}

Untuk analisis regresi dapat dilihat pada gambar 3. sebagai berikut:

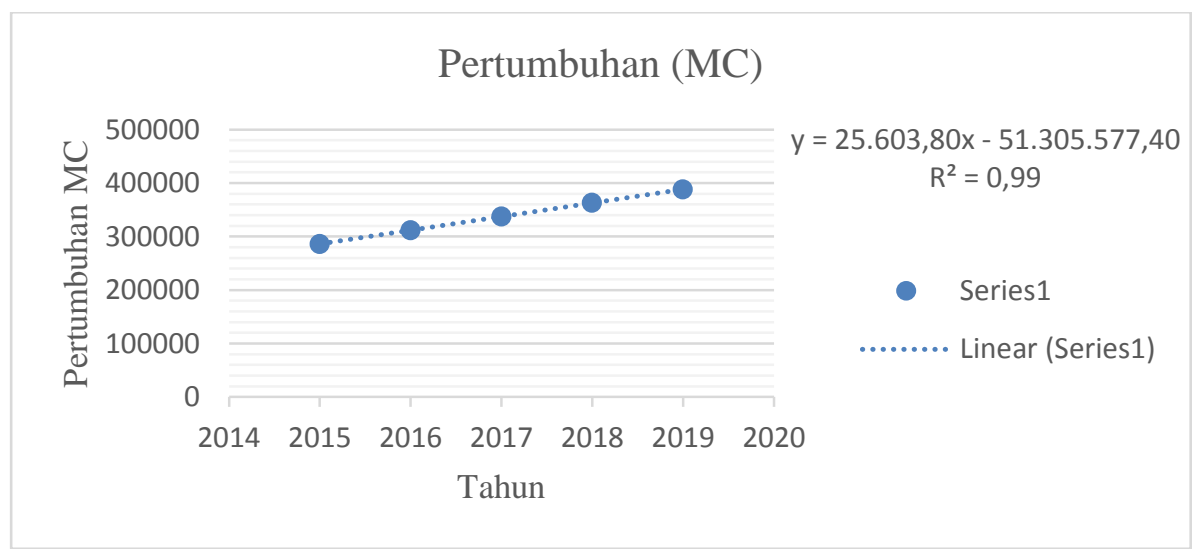

Gambar 3. Regresi Pertumbuhan MC

Tabel 3. Hasil Perhitungan Regresi Pertumbuhan Sepeda Motor (MC) dan Faktor Pertumbuhan MC

\begin{tabular}{ccc}
\hline No & Tahun & nilai y \\
\hline 1 & 2015 & 285911 \\
2 & 2016 & 311741 \\
3 & 2017 & 337304 \\
4 & 2018 & 363359 \\
5 & 2019 & 388121 \\
6 & 2020 & 418138,6 \\
7 & 2021 & 443744,4 \\
8 & 2022 & 469350,2 \\
9 & 2023 & 494956 \\
10 & 2024 & 520561,8 \\
11 & 2025 & 546167,6 \\
\hline Sumber: Hasil Perhitungan, tahun 2020
\end{tabular}

Pertumbuhan Kendaraan Penumpang (LV)

Pertumbuhan kendaraan penumpang dapat dilihat dalam tabel 4. dibawah ini :

Tabel 4. Pertumbuhan Kendaraan Penumpang (LV)

\begin{tabular}{cc}
\hline Tahun & Mobil (LV) \\
\hline 2015 & 31644 \\
2016 & 35057 \\
2017 & 38440 \\
2018 & 41969 \\
2019 & 45190 \\
\hline \multicolumn{2}{l}{ Sumber: UP3AD SAMSAT Kabupaten Banyumas }
\end{tabular}

Untuk analisis regresi dapat dilihat pada gambar 4. sebagai berikut: 


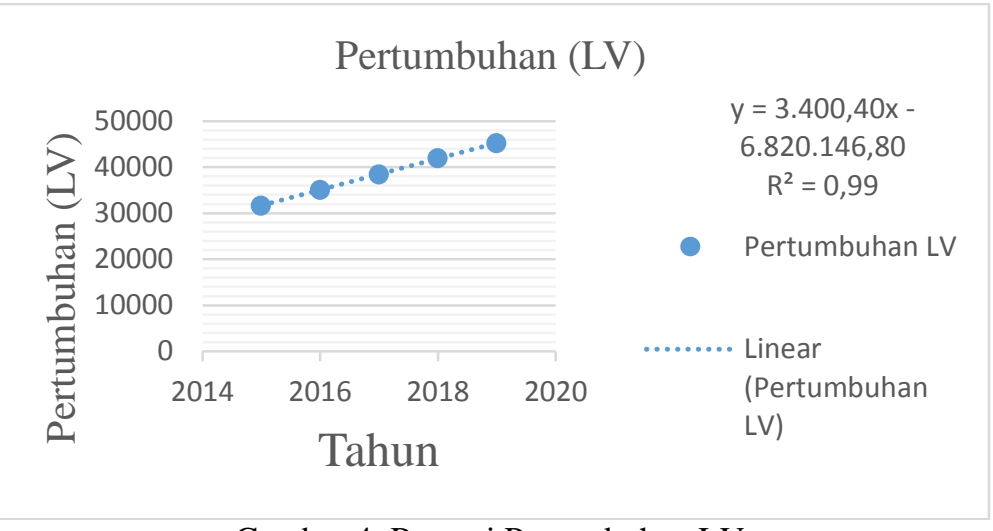

Gambar 4. Regresi Pertumbuhan LV

Tabel 5. Hasil Perhitungan Regresi Pertumbuhan LV dan Faktor Pertumbuhan LV

\begin{tabular}{ccc}
\hline No & Tahun & Nilai y \\
\hline 1 & 2015 & 31644 \\
2 & 2016 & 35057 \\
3 & 2017 & 38440 \\
4 & 2018 & 41969 \\
5 & 2019 & 45190 \\
6 & 2020 & 48661,2 \\
7 & 2021 & 52061,6 \\
8 & 2022 & 55462 \\
9 & 2023 & 58862,4 \\
10 & 2024 & 62262,8 \\
11 & 2025 & 65663,2 \\
\hline \multicolumn{2}{l}{ Sumber : Hasil Perhitungan, tahun 2020 }
\end{tabular}

Pertumbuhan kendaraan Berat (HV)

Pertumbuhan kendaraan berat dapat dilihat di tabel 6. dibawah ini:

Tabel 6. Pertumbuhan Kendaraan Berat (HV)

\begin{tabular}{cc}
\hline Tahun & Truk (HV) \\
\hline 2015 & 13389 \\
2016 & 14134 \\
2017 & 14979 \\
2018 & 15741 \\
2019 & 16328 \\
\hline \multicolumn{2}{l}{ Sumber :UP3AD SAMSAT Kabupaten Banyumas }
\end{tabular}

Untuk analisis regresi dapat dilihat pada gambar 5. sebagai berikut:

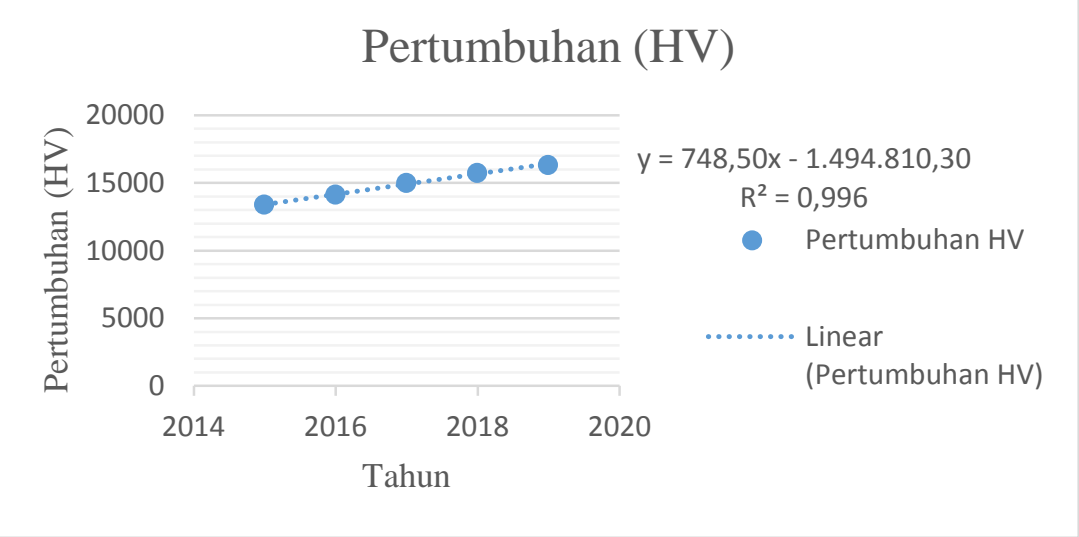

Gambar 5. Regresi Pertumbuhan HV 
Tabel 7. Hasil Perhitungan Regresi Pertumbuhan HV dan Faktor Pertumbuhan HV

\begin{tabular}{ccc}
\hline No & Tahun & Nilai y \\
\hline 1 & 2015 & 13389 \\
2 & 2016 & 14134 \\
3 & 2017 & 14979 \\
4 & 2018 & 15741 \\
5 & 2019 & 16328 \\
6 & 2020 & 17159,7 \\
7 & 2021 & 17908,2 \\
8 & 2022 & 18656,7 \\
9 & 2023 & 19405,2 \\
10 & 2024 & 20153,7 \\
11 & 2025 & 20902,2 \\
\hline Sumber: Hasil Perhitungan, tahun 2020
\end{tabular}

\subsection{Kependudukan}

Tabel 8. Data kependudukan kabupaten Banyumas

\begin{tabular}{|c|c|c|c|c|c|c|}
\hline \multirow{2}{*}{ No } & \multirow{2}{*}{ Kecamatan } & \multicolumn{5}{|c|}{ Tahun } \\
\hline & & 2015 & 2016 & 2017 & 2018 & 2019 \\
\hline 1 & Lumbir & 44189 & 44308 & 44416 & 44606 & 53060 \\
\hline 2 & Wangon & 75291 & 75654 & 75995 & 75965 & 87079 \\
\hline 3 & Jatilawang & 58690 & 58949 & 59193 & 59146 & 70823 \\
\hline 4 & Rawalo & 46907 & 47182 & 47445 & 47475 & 55682 \\
\hline 5 & Kebasen & 57576 & 57876 & 58161 & 58161 & 69653 \\
\hline 6 & Kemranjen & 65231 & 65730 & 66213 & 66370 & 75844 \\
\hline 7 & Sumpiuh & 51175 & 51392 & 51594 & 51547 & 60702 \\
\hline 8 & Tambak & 42743 & 42859 & 42962 & 43147 & 52777 \\
\hline 9 & Somagede & 33010 & 33210 & 33401 & 33425 & 39314 \\
\hline 10 & Kalibagor & 48010 & 48370 & 48717 & 48824 & 57724 \\
\hline 11 & Banyumas & 46520 & 46647 & 46759 & 46961 & 55504 \\
\hline 12 & Patikraja & 53422 & 53984 & 54536 & 54817 & 61457 \\
\hline 13 & Purwojati & 31742 & 31893 & 32035 & 31020 & 38948 \\
\hline 14 & Ajibarang & 94193 & 94952 & 95690 & 95955 & 106365 \\
\hline 15 & Gumelar & 46048 & 46172 & 46283 & 46484 & 55694 \\
\hline 16 & Pekuncen & 65980 & 66214 & 66430 & 66322 & 79088 \\
\hline 17 & Cilongok & 115819 & 117100 & 118366 & 119051 & 129242 \\
\hline 18 & Karanglewas & 62270 & 63248 & 64220 & 64874 & 67919 \\
\hline 19 & Kedungbanteng & 54062 & 54598 & 55123 & 55374 & 90637 \\
\hline 20 & Baturaden & 50824 & 51521 & 52211 & 52638 & 82537 \\
\hline 21 & Sumbang & 80644 & 81787 & 82923 & 83643 & 93838 \\
\hline 22 & Kembaran & 79166 & 80532 & 81897 & 82855 & 55376 \\
\hline 23 & Sokaraja & 83171 & 84366 & 85552 & 86310 & 62984 \\
\hline 24 & Purwokerto Selatan & 75564 & 76510 & 77445 & 77992 & 75436 \\
\hline 25 & Purwokerto Barat & 51892 & 52403 & 52903 & 53137 & 54591 \\
\hline 26 & Purwokerto Timur & 58246 & 58403 & 58544 & 58794 & 58995 \\
\hline 27 & Purwokerto Utara & 63524 & 64765 & 66011 & 66924 & 48883 \\
\hline
\end{tabular}

\subsection{Geometri}

Tabel 9.

\begin{tabular}{lllll}
\hline No & Keterangan & Jalur Purwokerto-Gumilir & Jl. Raya Kedungrandu & $\begin{array}{c}\text { Jl. Raya Patikraja- } \\
\text { Banyumas }\end{array}$ \\
\hline 1 & Tipe Jalan & Jalan tak terbagi 2 lajur, 2 & Jalan tak terbagi 2 lajur, 2 & Jalan tak terbagi 2 lajur, 2 \\
arah (2/2 UD) & arah (2/2 UD) & $3.75 \mathrm{~m}$ \\
2 & Lebar Pendekat & $3.9 \mathrm{~m}$ & $3.9 \mathrm{~m}$ & $1 \%$ \\
3 & Kelandaian & $1 \%$ & $1 \%$ & Rata dan datar \\
4 & Kondisi Jalan & Rata dan datar & Rata dan datar & Tidak ada \\
5 & Median & Tidak ada & Tidak ada & \\
\hline
\end{tabular}

CIVeng Vol.1, No.2, Juli $2020: 87 \sim 96$ 


\begin{tabular}{cclll}
\hline 6 & Lebar bahu jalan & $2.0 \mathrm{~m}$ dan $2.5 \mathrm{~m}$ & $2.0 \mathrm{~m}$ dan $2.0 \mathrm{~m}$ & $0.5 \mathrm{~m}$ dan $0.25 \mathrm{~m}$ \\
7 & Jenis Perkerasan & Aspal & Aspal & Aspa \\
\hline
\end{tabular}

Sumber : Wahyu Nurokhman, 2019

\subsection{Jam Puncak}

Tabel 10. Hasil analisa jam puncak kendaraan Smp/jam, Tahun 2019

\begin{tabular}{lccl}
\hline \multicolumn{1}{c}{$\begin{array}{c}\text { Tabel 4.4 Hasil analisa jam puncak } \\
\text { kendaraan Smp/jam Arah Arus }\end{array}$} & Hari & Jam (WIB) & Smp/jam \\
\hline Rawalo-Banyumas & Sabtu & $09.15-10.15$ & 919,6 \\
Rawalo-Purwokerto & Selasa & $06.45-07.45$ & 596,9 \\
Banyumas-Purwokerto & Selasa & $06.30-07.30$ & 93,9 \\
Banyumas-Rawalo & Sabtu & $17.00-18.00$ & 965,2 \\
Purwokerto-Banyumas & Selasa & $16.00-17.00$ & 240 \\
Purwokerto-Rawalo & Selasa & $16.15-17.15$ & 567,5 \\
\hline Sumber: Wahyu Nurokhman, tahun 2019 & & &
\end{tabular}

\subsection{Tingkat Pelayanan}

Tingkat Pelayanan 2020

a. Kapasitas Simpang (C)

$\mathrm{C}=C_{O} \times F_{W} \times F_{M} \times F_{C S} \times F_{R S U} \times F_{L T} \times F_{R T} \times F_{M I}$

$\mathrm{C}=2700 \times 1.02 \times 1 \times 0,82 \times 0,94 \times 1,41 \times 0,81 \times 0,93$

$\mathrm{C}=2273 \mathrm{Smp} / \mathrm{jam}$

b. Arus total sesungguhnya (smp/jam) (Qsmp)

$Q \operatorname{smp}=1884,8+1164,4+333,9$

$Q \operatorname{smp}=3383$

c. Derajat Kejenuhan (DS)

$\mathrm{DS}=$ Qsmp / C

$\mathrm{DS}=3383 / 2273=1,49 \geq 0,75$ (Jenuh)

Derajat kejenuhan untuk semua ruas $1,49 \geq 0,75$

\section{Pemecahan Masalah 2020}

- Skenario I

Perubahan yang dilakukan yaitu dengan melebarkan jalan utama B dan jalan utama D dengan pelebaran 4 meter dan jalan minor $\mathrm{C}$ dengan pelebaran $75 \mathrm{~cm}$ dari kondisi awal.

a. Kapasitas Simpang (C)

$$
\begin{aligned}
& \mathrm{C}=C_{O} \times F_{W} \times F_{M} \times F_{C S} \times F_{R S U} \times F_{L T} \times F_{R T} \times F_{M I} \\
& \mathrm{C}=2700 \times 1.13 \times 1 \times 0,82 \times 0,94 \times 1,41 \times 0,81 \times 0,93 \\
& \mathrm{C}=2520 \mathrm{Smp} / \mathrm{jam}
\end{aligned}
$$

b. Arus total sesungguhnya ( $\mathrm{smp} / \mathrm{jam})(Q s m p)$

$$
\text { Qsmp }=1884,8+1164,4+333,9
$$

Qsmp $=3383$

c. Derajat kejenuhan (DS)

$\mathrm{DS}=Q \operatorname{smp} / \mathrm{C}$

$\mathrm{DS}=3383 / 2520=1,34 \geq 0,75$ (Jenuh)

- Skenario II

Analisis selanjutnya dengan perencanaan bundaran pada persimpangan Jl. Raya Pasar Patikrajadengan diameter bundaran yaitu $4 \mathrm{~m}$.

a. Kapasitas Simpang

- $C_{d c}=135 \times w_{W}^{1,3} \mathrm{x}\left(1+W_{E} / W_{W}\right)^{1,5} \mathrm{x}\left(1-P_{W} / 3\right)^{0,5} \mathrm{x}\left(1+W_{W} / L_{W}\right)^{-1,8} \mathrm{x} F_{C S} \mathrm{x} F_{R S U}$ $C_{d c}=1117 \times 3,096 \times 0,95 \times 0,525 \times 0,82 \times 0,93$

$C_{d c}=1316 \mathrm{Smp} / \mathrm{jam}$

- $\quad C_{c b}=135 \times W_{W}{ }^{1,3} \times\left(1+W_{E} / W_{W}\right)^{1,5} \times\left(1-P_{W} / 3\right)^{0,5} \times\left(1+W_{W} / L_{W}\right)^{-1,8} \times F_{C S} \times F_{R S U}$

$C_{c b}=1117 \times 2,824 \times 0,95 \times 0,525 \times 0,82 \times 0,93$

$C_{c b}=1201 \mathrm{Smp} / \mathrm{jam}$ 
- $\quad C_{b d}=135 \times w_{W}^{1,3} \times\left(1+W_{E} / W_{W}\right)^{1,5} \times\left(1-P_{W} / 3\right)^{0,5} \times\left(1+W_{W} / L_{W}\right)^{-1,8} \times F_{C S} \times F_{R S U}$ $C_{b d}=1120 \times 3,091 \times 0,95 \times 0,588 \times 0,82 \times 0,93$

$C_{b d}=1475 \mathrm{Smp} / \mathrm{jam}$

b. Arus total sesungguhnya (smp/jam) $(Q s m p)$

- $Q_{d c} \operatorname{smp}=808+597$

$Q_{d c} \operatorname{smp}=1404$

- $Q_{c b} s m p=1059+808$

$Q_{c b} s m p=1867$

- $Q_{b d} \operatorname{smp}=94+1517$

$Q_{b d} \operatorname{smp}=1610$

c. Derajat Kejenuhan (DS)

- $D S_{d c}=Q_{d c} \operatorname{smp} / C_{d c}$

$D S_{d c}=1404 / 1316$

$D S_{d c}=1,07 \geq 0,75$ (Jenuh)

- $D S_{c b}=Q_{c b} \operatorname{smp} / C_{c b}$

$D S_{c b}=1867 / 1202$

$D S_{c b}=1,55 \geq 0,75$ (Jenuh)

- $D S_{b d}=Q_{b d} s m p / C_{b d}$

$D S_{b d}=1610 / 1475$

$D S_{b d}=1,09 \geq 0,75$ (Jenuh)

- $\quad$ Skenario III

Kenapa simpang tersebut di rubah menjadi simpang bersinyal, karena saya sudah melakukan pelebaran semaximal mungkin dan pemberian bundaran dengan diameter 4 meter dengan tujuan mengikuti permintaan dari dosen pembimbing tetapi di simpang tiga JL. Raya Pasar Patikraja tetapi masih mengalami kejenuhan. Sehingga saya mengambil inisiatif di skenario selanjutnya dilakukan perubahan tipe simpang menjadi bersinyal dengan menggunakan 3 fase

- Penentuan waktu sinyal :

- Waktu siklus $\mathrm{C}=55$ detik

- Waktu hijau :

a. giB $=36$ detik

b. $\mathrm{giC}=30$ detik

c. $\operatorname{gibD}=35$ detik

1) Kapasitas Simpang ( C )

- $\mathrm{C}=\mathrm{S} \times \frac{g}{c}$

- $\mathrm{CB}=1658 \times \frac{36}{55}=995 \mathrm{smp} / \mathrm{jam}$

- $\mathrm{CC}=2674 \times \frac{30}{55}=1337 \mathrm{smp} / \mathrm{jam}$

- $\mathrm{CD}=3060 \times \frac{35}{55}=1785 \mathrm{smp} / \mathrm{jam}$

2) Arus total sesungguhnya

- $\mathrm{QB}=684,4+51,3$ $\mathrm{QB}=735,7 / 736$

- $\mathrm{QC}=326,9+148,8$ $\mathrm{QC}=475,7 / 476$

- $\mathrm{QD}=634,6+306,8$ $\mathrm{QD}=941,4 / 941$

3) Drajat Kejenuhan (DS)

- $\mathrm{DS}=\frac{Q}{C}$ 
- $\mathrm{DS}_{\mathrm{B}}=\frac{736}{995}=0,74$

- $\mathrm{DS}_{\mathrm{C}}=\frac{476}{1337}=0,36$

- $\mathrm{DS}_{\mathrm{D}}=\frac{941}{1785}=0,53$

- $\mathrm{DS}_{\text {total }}=\frac{2153}{4117}=0,52$

Dari perhitungan diatas didapat derajat kejenuhan :
a. Ruas rawalo: $0,74 \leq 0,75$
b. Ruas Purwokerto $\quad: 0,36 \leq 0,75$
c. Ruas Banyumas : $0,53 \leq 0,75$
Derajat kejenuhan untuk semua ruas $0,52 \leq 0,75$ (Tidak Jenuh)

\section{Tingkat Pelayanan 2025}

Dari hasil perencanaan didapat tingkat pelayanan sebagai berikut :

- Penentuan waktu sinyal :

- Waktu siklus

$\mathrm{C}=65$ detik

- Waktu hijau :
a. $\quad \mathrm{gaB}=40$ detik
b. $\mathrm{giC}=35$ detik
c. giD $=45$ detik

1) Kapasitas Simpang (C)

- $\mathrm{C}=\mathrm{S} \times \frac{g}{c}$

- $\mathrm{CB}=1658 \times \frac{40}{65}=1021 \mathrm{smp} / \mathrm{jam}$

- $\mathrm{CC}=1948 \times \frac{35}{65}=1049 \mathrm{smp} / \mathrm{jam}$

- $\mathrm{CD}=3060 \times \frac{45}{65}=2119 \mathrm{smp} / \mathrm{jam}$

2) Arus total sesungguhnya

- $\mathrm{QB}=684,4+51,3$

$\mathrm{QB}=735,7 / 736$

- $\mathrm{QC}=326,9+148,8$

$\mathrm{QC}=475,7 / 476$

- $\mathrm{QD}=634,6+306,8$

$\mathrm{QD}=941,4 / 941$

- $\mathrm{Qtotal}=736+476+941$

Qtotal $=2153$

3) Drajat Kejenuhan (DS)

- $\mathrm{DS}=\frac{Q}{C}$

- $\mathrm{DS}_{\mathrm{B}}=\frac{{ }^{C}}{1336}=0,72$

- $\mathrm{DS}_{\mathrm{C}}=\frac{476}{1049}=0,45$

- $\mathrm{DS}_{\mathrm{D}}=\frac{941}{2119}=0,44$

- $\mathrm{DS}_{\text {total }}=\frac{2153}{4188}=0,51$

Dari perhitungan diatas didapat derajat kejenuhan :
a. Ruas rawalo: $0,72 \leq 0,75$
b. Ruas Purwokerto $\quad: 0,45 \leq 0,75$
c. Ruas Banyumas $: 0,44 \leq 0,75$

Derajat kejenuhan untuk semua ruas $0,51 \leq 0,75$ (Tidak Jenuh) 
4. KESIMPULAN

Berdasarkan analisis kinerja simpang di Jalan Raya Pasar Patikraja dapat disimpulkan sebagai berikut :

1. Pada simpang tiga tak bersinyal Jalan Raya Pasar patikraja pada tahun 2019, didapat volume lalu lintas sebesar $5400 \mathrm{kend} / \mathrm{jam}$ dan nilai DS $=1,49 \geq 0,75$ (sangat jenuh). Sehingga dilakukan beberapa penanganan. Dari beberapa skenario yang dilakukan, terpilihskenario III, yaitu dengan perubahan teknis simpang tak bersinyal menjadi simpang bersinyal menggunakan 3 fase diperoleh nilai DS $=0,52 \leq 0,75$ (tidak jenuh), yaitu kondisi dimana suatu simpang tidak mengalami kemacetan/keramia.

2. Pada simpang bersinyal di Jalan Raya Pasar Patikraja untuk 5 tahun mendatang (2025). Dengan menggunakan skenario III di dapat $\mathrm{DS}=0,51 \leq 0,75$ (tidak jenuh), yaitu kondisi dimana suatu simpang tidak mengalami kemacetan.

\section{DAFTAR PUSTAKA}

[1] Amtoro, A. R. (2016). Analisis Kinerja Simpang Tak Bersinyal Empat Lengan (Studi Kasus Simpang Tak Bersinyal Empat Lengan Jalan Wates Km 5, Gamping, Sleman, Yogyakarta) (Doctoral dissertation, UII Yogyakarta).

[2] Edward K. Marlok, 1991, Buku Pengantar Teknik dan Transportasi.

[3] Hasanudin, M. A. U., Timboeleng, J. A., \& Longdong, J. (2019).AnalisisKinerja Lalu Lintas Persimpangan Lengan Empat TakBerinyal (Studi Kasus: Persimpangan Jalan Banje).Jurnal SipilStatik, 7(11).

[4] Kamus Besar Bahasa Indonesia. [online]. Tersedia di kbbi.kemdikbud.go.id/entri /simpang. Diakses 1 febuari 2020.

[5] Listiana, N., \& Sudibyo, T. (2017). Analisis Kinerja Simpang Tak Bersinyal Jalan Raya Dramaga-Bubulak Bogor, Jawa Barat. Jurnal Teknik Sipil dan Lingkungan, 2(2), 59-68.

[6] Marlok, 1997

[7] MKJI (1997). Manual Kapasitas Jalan Indonesia (MKJI), Direktorat Jendral Bina Marga departemen Pekerjaan Umum, Jakarta.

[8] Nurokhman, Wahyu. (2019). Analisis Kinerja Simpang TigaTak Bersinyal JalanRaya Pasar Patikraja, Skripsi, FTS, UMP Purwokerto.

[9] Soekarno, Dkk, 2003 